Dokuz Eylül Üniversitesi-Mühendislik Fakültesi

Fen ve Mühendislik Dergisi

Cilt 20, Sayı 59, Mayıs, 2018
Dokuz Eylul University-Faculty of Engineering Journal of Science and Engineering Volume 20, Issue 59, May, 2018

DOI: $10.21205 /$ deufmd. 2018205941

\title{
Determination of the Shear Strength Parameters of Flow Band Structures in Andesites under Static and Dynamic Conditions
}

\author{
Ahmet Turan ARSLAN*, Bayram KAHRAMAN \\ Dokuz Eylül University, İzmir Vocational School, Buca, İzmir/TURKEY \\ (ORCID: 0000-0002-8018-1707) \\ Department of Mining Engineering, Engineering Faculty, Dokuz Eylül University, Buca \\ İzmir/TURKEY (ORCID: 0000-0001-9429-6591)
}

(Alınış / Received: 06.09.2017, Kabul / Accepted: 28.12.2017, Online Yayınlanma / Published Online: 15.05.2018)

Keywords Shear test Shear strength Dynamic testing Flow bands Andesite

\begin{abstract}
Stability and deformation analyses of geotechnical projects such as tunnels, underground excavations and rock slopes require reliable data about the behavior of discontinuities (joints, fractures, bedding planes and etc.). Therefore, shear box tests are widely used in rock mechanics applications. In this study, several static and dynamic shear box tests were carried out both over flow bands of the andesites which cover a large area in the northern part of Izmir Bay. Shear box tests were conducted under both static and dynamic conditions on rectangular planes with a dimension of $400 \times 200 \mathrm{~mm}$. As a result of these tests, normal displacement-normal stress, shearing displacement-shearing stress and normal displacement-shear strength correlations were obtained. Also, peak and residual shear strength values, base friction angle and residual friction angle were found and the results were interpreted. Thus, the shear strength properties of the flow band structures can be given with more accuracy. Based on the new findings, more realistic solutions will be obtained in numerical analyses and simulation models aiming at determining the stability of underground excavations and engineering projects on the ground surface will be more reliable.
\end{abstract}

\section{Andezitlerdeki Akma Bantlarının Makaslama Dayanım Parametrelerinin Statik ve Dinamik Koşullar Altında Belirlenmesi}

\begin{abstract}
Anahtar Kelimeler Makaslama deneyi Makaslama dayanımı Dinamik test Akma bantı Andezit

Özet: Tüneller, yeraltı kazıları kaya şevleri gibi jeoteknik projelere ait stabilite ve deformasyon analizleri, süreksizliklerin (eklemler, çatlaklar, tabakalanma düzlemleri vb.) davranıșları hakkında güvenilir verilere ihtiyaç duymaktadır. Bu nedenle makaslama kutusu deneyleri, kaya mekaniği uygulamalarında yaygın bir şekilde kullanılmaktadır. Bu çalışmada, İzmir Körfezi kuzeyinde geniş alanlar kaplayan andezitlerdeki akma bantları üzerinde statik ve dinamik koşullarda makaslama kutusu deneyleri
\end{abstract}


yapılmıştır. Makaslama deneyleri 400 x 200 mm dikdörtgen şekilli geniş yüzeyler üzerinde statik ve dinamik koşullarda yapılmıştır. Statik koşullarda yapılan deneylerde, zaman - yer değiştirme; zaman - gerilme; makaslama yer değiștirmesi - gerilme; makaslama yer değiştirmesi - normal yer değiştirme; makaslama yer değiştirmesi - makaslama gerilmesi; normal gerilme makaslama gerilmesi ilişkileri elde edilerek doruk ve artık makaslama dayanımları, temel sürtünme açısı ve artık sürtünme açısı değerleri bulunarak sonuçlar yorumlanmıştır. Dinamik koşullarda yapılan deneylerde ise, makaslama yer değiştirmesi zaman, makaslama gerilmesi - zaman, makaslama yer değiştirmesi - makaslama gerilmesi - zaman, makaslama gerilmesi - makaslama yer değiştirmesi, normal yer değiştirme zaman ilişkileri elde edilmiş ve sonuçlar yorumlanmıştır. Andezitlerdeki akma bantlarında yapılan makaslama kutusu deneyleri sonucunda; akma bantlarının dayanım özellikleri daha gerçekçi olarak tanımlanacak, nümerik analiz programları ve nümerik simülasyonlar kullanılarak depremlere bağlı olarak andezitlerdeki yer altı ve yerüstü kaya yapılarının duraylılığını belirlemeye yönelik modellemelerde daha gerçekçi çözümler elde edilecektir

*Sorumlu yazar: ahmet.arslan@deu.edu.tr

\section{Introduction}

Most of the rock mass has discontinuities such as bedding planes, joints, shear zones and faults. Failures are rarely seen in rock material in the shallow depths having low stress and the behaviour of the rock mass is controlled by discontinuities. To analyze a rock block's stability, factors controlling shear strength of the discontinuities separating rock blocks must be considered. Rock mass properties should be revealed after field works and design must be conducted using the data. Izmir is considered one of the most irregular urbanized cities in Turkey. Especially, this problem is faced with in the southern and northern districts of the Izmir Bay Koca (1995), Koca and Kincal (2004). Discontinuity controlled instabilities are frequently seen in andesites in the region. Falling, toppling and sliding type slope movements are observed around existing slope cuts and abandoned stone quarries. Rock units provide a suitable base for foundations unless they are highly fractured, weathered and porous media. Geotechnical properties of rocks include discontinuities, thickness of the rock unit, weathering grade and porosity. Safe bearing capacity of rock mass will be decreased if it is highly fractured. Even if they bear the overlying loads safely, there will be shear deformations because of the opening and sliding of the discontinuities. For this reason, positions (attitudes) and properties of the discontinuities which foundations will be placed on is critical. Resistance parameters (e.g. c, $\phi$ ) which affect the shear stresses must be determined precisely to judge the problem mentioned above. These parameters are determined via portable (in-situ) or in laboratory-designed shearing testing devices (Jing et al., 1993; Geertsma, 2002; Seidel and Haberfield, 2002; Kim et al., 2006; Wang el al., 2007; Gomez et 
al., 2008; Buzzi et al., 2008; Barla et al., 2007, 2010; Konietzky et al., 2012b). The shear behaviour of rock joints has been investigated by many researchers under both constant normal load (Barton, 1976; Gentier, et al., 2000; Grasselli and Egger, 2003; Belem, et al., 2004; Jiang, et al., 2006; Kim and Lee, 2007; Asadi and Rasouli, 2012) and constant normal stiffness (Ohnishi and Dharmaratne, 1990; Kodikara and Johnston, 1994; Haberfield and Seidel, 1999; Haque, 1999; Jiang, et al., 2004).

\section{Geology of the Study Area}

The Upper Cretaceous-Paleocene aged Bornova Melange rocks exposed in Izmir Metropolitan area mainly consist of conglomerate, micritic limestone, Bornova Flysch and limestone olistolithes in the flysch matrix. Bornova Melange is highly folded and fractured by the effect of tectonic activities. Neogene sedimentary rocks, consisting of conglomerate, sandstone, siltstone, mudstone, and limestone, discordantly overlie the melange (Fig.1) Miocene volcanics mainly consisted of dasitic tuff, dasitic lava, and andesitic lava subunits, were identified and mapped. Modern faults and shear zones are developed from the cooling joints in the andesitic and dasitic lavas. Shear zones which are parallel to the cooling joints strike in NE-SW direction, are especially wide spread in south of the bay (Koca, 1995). The similar shear zones in north of the bay can be seen in abandoned stone quarries. The major cooling joints in the andesitic and dacitic lavas strike NE-SW and NW-SE directions were affected by the tectonic activities. surfaces can be smooth or rough; in good contact or poor contact; filled or not. Rock mass behaviour under low stress conditions is mostly controlled by sliding along existing discontinuities rather than failure of the intact rock mass (Hoek, 2007). This means that the shear strength of a discontinuity in rock mass may have a strong impact on the mechanical behaviour of rock joints in engineering structures (slopes, foundations, tunnels, etc.). The behaviour of rock discontinuities is still not very well investigated and understood in general and especially under dynamic loads. Large-size underground structures such as storage caverns and radioactive waste repositories or dams require a high standard of resistance against blasting and earthquake loads. Therefore, the dynamic shear behaviour of rock joints becomes more important for engineers (Nguyen, 2013). The most popular method currently used to determine the joint shear strength is a direct shear test which can be performed in the field and in the laboratory using a direct shear apparatus. The shear behaviour of flow bands is studied in laboratory under CNL (Constant Normal Load) and dynamic boundary conditions.

Rock masses comprise rock material as well as discontinuities and the effects of the discontinuities on rock mass must be determined for engineering applications. Therefore, scan-line works have been done to determine the properties of flow band structures by Koca and Kincal (2004) and Koca et al. (2006) according to ISRM (1981).

\section{Shear Strength of Andesitic Flow Bands}

Natural rock masses always contain discontinuities. The discontinuity 


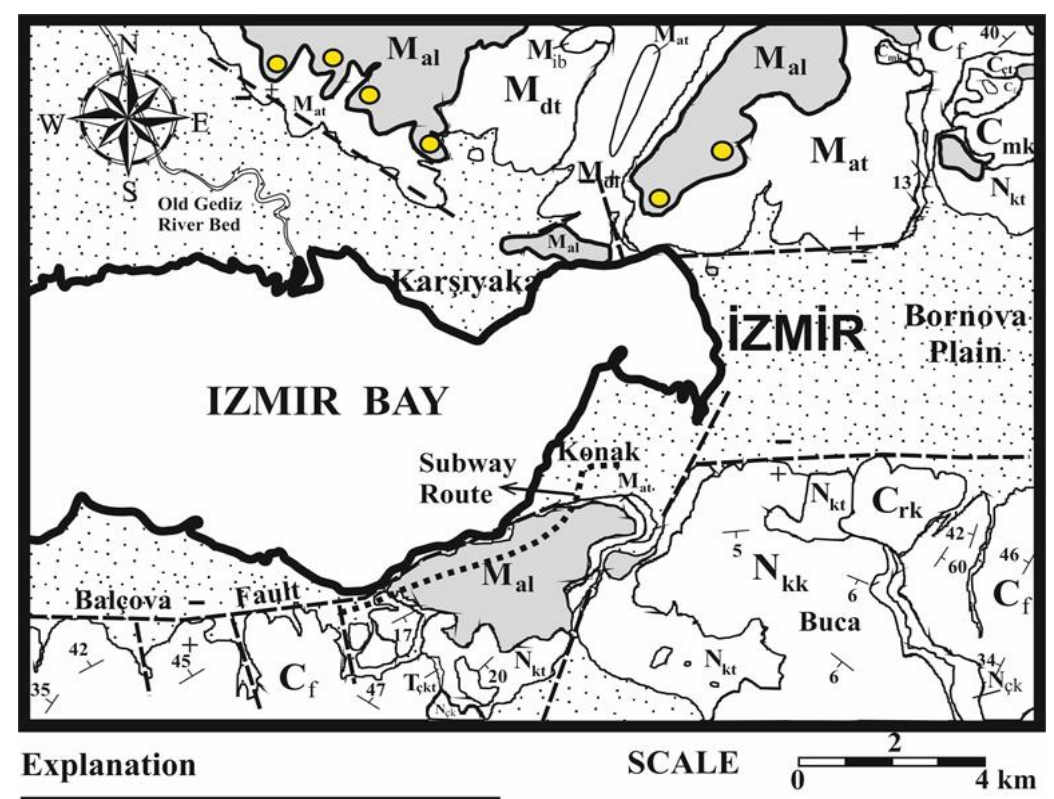

\begin{tabular}{|c|c|c|c|}
\hline \multicolumn{2}{|c|}{ Quaternary } & & Slope wash/Alluvium \\
\hline \multirow{10}{*}{$\begin{array}{l}1 \\
z \\
0 \\
0 \\
0 \\
0 \\
z \\
z\end{array}$} & \multirow{10}{*}{$\begin{array}{l}\text { w } \\
z \\
\text { w } \\
0 \\
0 \\
\text { z } \\
\bar{z}\end{array}$} & \begin{tabular}{l|l|l|}
$M_{i b}$ & $M_{d d}$ \\
$M_{l}$
\end{tabular} & $\begin{array}{l}\text { Intrusion breccia } \\
\text { Silicified dasitic dykes } \\
\text { Felsic intrusion }\end{array}$ \\
\hline & & $\mathbf{M}_{\mathrm{al}}$ & Andesite lava \\
\hline & & $\mathbf{M}_{\text {at }}$ & Agglomerate $\begin{array}{c}\text { Flow breccia } \\
\text {-Lahar }\end{array}$ \\
\hline & & & $\begin{array}{l}\text {-Agglomerate } \\
\text {-Andesitic tuff }\end{array}$ \\
\hline & & $\mathbf{M}_{\mathrm{dl}}$ & Dasitic lava \\
\hline & & $\mathbf{M}_{\mathrm{dt}}$ & Dasitic tuff \\
\hline & & & Limestone \\
\hline & & & Marl/Clayey limestone \\
\hline & & ck & Conglomerate \\
\hline & & $\mathbf{T}_{\text {çkt }}$ & Basal conglomerate \\
\hline
\end{tabular}

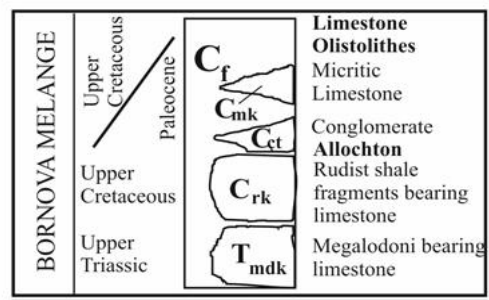

\begin{tabular}{|l|l|}
\hline \multicolumn{3}{|r|}{ Strike and dip of beds } \\
\hline$-1+$ & Main normal fault \\
\hline 0 & Sampling locations \\
\hline
\end{tabular}

Figure 1. Simplified geological map of the Izmir metropolitan area and locations of the andesite quarries (Koca, 1995)

Attitudes of the flow band structures obtained with the help of scan-line works and detailed properties of the flow bands were given in Table 1

Table 1. Flow bands properties obtained from scanlines (Koca and Kıncal 2004)

\begin{tabular}{l|l}
\hline & Flow bands \\
\hline Bedding plane and joint spacing & $1-3 \mathrm{~cm}$ (moderately narrow) generally closely spaced \\
& joints \\
Width of apertures & Generally closed joints \\
Persistence & $1.5-3.5 \mathrm{~m}$ low persistence \\
\hline
\end{tabular}


A.T. Arslan/ Determination of the Shear Strength Parameters of Flow Band Structures in Andesites under Static and Dynamic Conditions

Table 2. The values of the first and second order asperity angles measured on the profiles for the flow band surfaces

\begin{tabular}{|c|c|c|c|c|c|}
\hline \multirow[b]{2}{*}{ Location } & \multirow[b]{2}{*}{$\begin{array}{l}\text { Discontinuity } \\
\text { type }\end{array}$} & \multicolumn{2}{|c|}{$\begin{array}{l}\text { The number of } \\
\text { measurements }\end{array}$} & \multirow{2}{*}{$\begin{array}{l}\text { Mean second } \\
\text { order } \\
\text { asperity } \\
\text { angle } \\
\text { (degree) } \\
\left(\mathrm{i}_{2}\right)\end{array}$} & \multirow{2}{*}{$\begin{array}{l}\text { Mean first } \\
\text { order } \\
\text { asperity } \\
\text { angle } \\
\text { (degree) } \\
\text { (i } 1 \text { ) } \\
\end{array}$} \\
\hline & & $\begin{array}{l}\text { For the first } \\
\text { order } \\
\text { asperity }\end{array}$ & $\begin{array}{l}\text { For the } \\
\text { second order } \\
\text { asperity }\end{array}$ & & \\
\hline $\begin{array}{l}\text { Osmangazi } \\
\text { quarries }\end{array}$ & Flow bands & 38 & 338 & $20.97 \pm 9.55$ & $14.40 \pm 3.28$ \\
\hline
\end{tabular}

In-situ and laboratory roughness measurements were carried out on flow band structures in andesites and presented in Table 2. And also, a graph was prepared to show the second order asperities is also given in Fig. 2. It can be said that flow band surfaces are rough, very rough and undulating according to the classification suggested by ISRM (2007). A contour diagram was prepared for the Osmangazi Quarry-4 using 84 field measurements (Fig.3). Pole concentration point is obtained from the contour diagram (Fig.3). To carry out shear box tests on flow band surfaces, six block samples were obtained in the locations where scanline works were conducted. The range of normal stress was chosen as 3-10-15$20 \mathrm{MPa}$ to represent the field conditions and used during the tests. During the shear box tests, GS 1000 shear box test equipment were used in TU Bergakademie Freiberg İnstitüt für Geotechnik Gesteinsmechaniklabor, Germany. GS 1000 shear box device has the maximum capacity of $1000 \mathrm{kN}$ normal force, $300 \mathrm{kN}$ tensile force, + $800 \mathrm{kN}$ shear force, $\pm 500 \mathrm{kN}$ dynamic load $(40 \mathrm{~Hz})$ for both directions.

\section{Mechanical, Elastical and Dynamic Properties of Andesites}

Andesite block samples were obtained in northern part of the Izmir Bay to determine mechanical, elastical and dynamic properties of andesites, behavior models during earthquakes experimentally, empirically and with the help of mathematical models and to determine what kind of movement foundations on andesites will be exposed to. Core samples obtained from the rock block samples and physical and mechanical properties of the andesite core samples were tested in TU Bergakademie in Germany. Compression wave velocity $\left(\mathrm{V}_{\mathrm{P}}\right)$, Shear wave velocity $\left(\mathrm{V}_{\mathrm{s}}\right)$, Dynamic Elasticity Modulus (ED), Shear Modulus (G), Poisson's Ratio ( $v$ ) parameters were determined for andesite samples using the Ultraschall-generator USG21 Geotron-Elektronik TransientenRecorder TRB 4000 seismic analyzer according to ISRM (2007) and results were given in Table 3.

Uniaxial compressive strength (UCS) tests (loading-unloading stepped) were conducted using TIRAtest 28500 test device applying $2.0 \mathrm{MPa} / \mathrm{min}$ on a rock unit according to DGGT (2004b) and results were given in Table 4 . Static triaxial compressive strength (STCS) tests were conducted using MTS 815 test device applying axial force at a rate of $4 \mathrm{kN} / \mathrm{min}$ and confining pressure at 1 $\mathrm{MPa} / \mathrm{min}$ on three rock units according to ISRM (1983). Results are given in Table 5. Dynamic triaxial compressive strength (DTCS) tests were conducted using MTS 815 test device. After applying a static axial force at a rate of 4 $\mathrm{kN} / \mathrm{min}$ and confining pressure at 1 $\mathrm{MPa} / \mathrm{min}$ dynamic (cyclic) axial loading was superimpozed with a dynamic 
peak-to-peak-amplitude of $5 \mathrm{kN}$ at a frequency of $2.0 \mathrm{~Hz}$ for $300 \mathrm{~s}$. After a dynamic loading sequence the center amplitude was raised $8\left(\mathrm{n}_{\text {dyn }}\right)$ times by the step value of $2.55 \mathrm{MPa}\left(\Delta \sigma_{\text {dyn }}\right)$. Loading parameters are given in Table 6.

\section{Shear Testing Device}

The most commonly used method for testing the shear behaviour of rock joints is the direct shear test. This type of test is usually carried out in the laboratory, but it may also be performed in the field. In recent years, several commercial

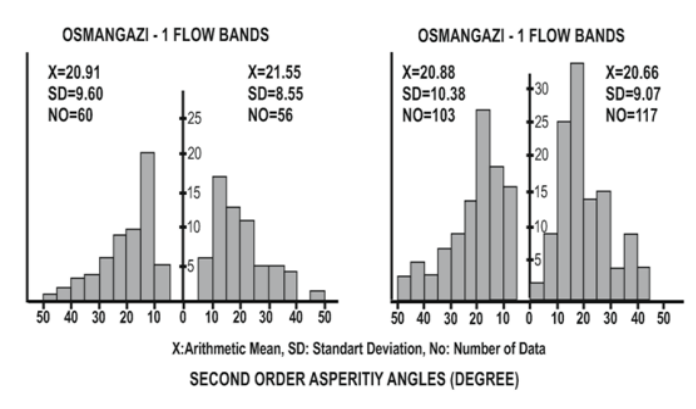

Figure. 2 Frequency distributions of the second order asperity angles of flow bands. producers have developed shear box devices for rock mechanical testing (e.g. MTS-816, GCTSRDS-500, TerraTek-DS4250, LO-5010, HR72.340).

The technical data show maximum normal forces between $500 \mathrm{kN}$ and $1500 \mathrm{kN}$, maximum shear forces between $250 \mathrm{kN}$ and $750 \mathrm{kN}$ and maximum shear box dimensions between $100 \mathrm{~mm}$ and $350 \mathrm{~mm}$. A summary of technical data for several direct shear box devices is presented in Table

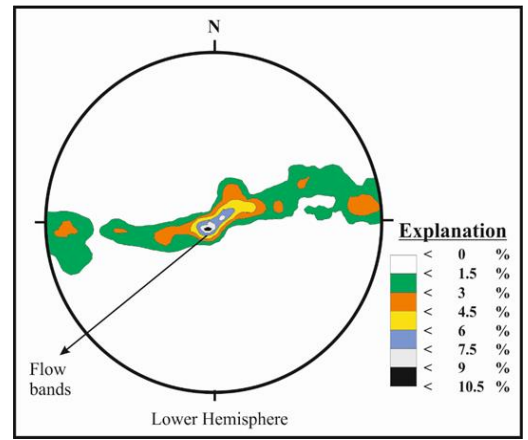

Figure 3. Contour diagram prepared using the flow band orientations of andesites from the northern part of Izmir Bay.

Table 3. Dynamic elastic coefficients of the samples.

\begin{tabular}{cccccc}
\hline $\begin{array}{c}\text { Lithological } \\
\text { Unit }\end{array}$ & $\begin{array}{c}\text { VP Wave } \\
\text { Velocity } \\
(\mathrm{m} / \mathrm{sn})\end{array}$ & $\begin{array}{c}\text { Vs Wave } \\
\text { Velocity } \\
(\mathrm{m} / \mathrm{sn})\end{array}$ & $\begin{array}{c}\text { Elastisity Modulus } \\
\text { (GPa) }\end{array}$ & $\begin{array}{c}\text { Shear } \\
\text { Modulus } \\
\text { (GPa) }\end{array}$ & $\begin{array}{c}\text { Poisson's } \\
\text { Ratio }\end{array}$ \\
\hline \multirow{3}{*}{ Andesite } & 4138 & 2544 & 35.66 & 14.91 & 0.20 \\
& 4245 & 2608 & 38.44 & 16.06 & 0.20 \\
& 4126 & 2437 & 33.43 & 13.57 & 0.23 \\
\hline
\end{tabular}

Table 4. Loading-unloading stepped uniaxial compressive strength test results.

\begin{tabular}{|c|c|c|c|c|}
\hline \multirow[b]{2}{*}{$\begin{array}{c}\text { Lithological } \\
\text { Unit }\end{array}$} & \multirow{2}{*}{$\begin{array}{c}\mathrm{UCS} \\
\left(\sigma_{\mathrm{c}}\right) \\
(\mathrm{MPa})\end{array}$} & \multirow{2}{*}{$\begin{array}{l}\text { Modulus of } \\
\text { Deformation } \\
(\mathrm{GPa})\end{array}$} & \multicolumn{2}{|c|}{ Young's Modulus (GPa) } \\
\hline & & & Unloading Cycle & Reloading Cycle \\
\hline Andesite & 72.11 & 23.68 & 34.76 & 35.18 \\
\hline
\end{tabular}


A.T. Arslan/ Determination of the Shear Strength Parameters of Flow Band Structures in Andesites under Static and Dynamic Conditions

Table 5. Triaxial compression test results. Stresses at peak strength are given.

\begin{tabular}{cccccccc}
\hline Lithology & $\begin{array}{c}\left(\sigma_{3}\right) \\
(\mathrm{MPa})\end{array}$ & $\begin{array}{c}\left(\sigma_{1}\right) \\
(\mathrm{MPa})\end{array}$ & $\begin{array}{c}\left(\sigma_{1}-\sigma_{3}\right) \\
(\mathrm{MPa})\end{array}$ & $\begin{array}{c}\text { Internal Friction } \\
\text { Angle } \\
(\phi)\left({ }^{\circ}\right)\end{array}$ & $\begin{array}{c}\text { Cohesion } \\
(\mathrm{c})(\mathrm{MPa})\end{array}$ & $\begin{array}{c}\text { Elasticity } \\
\text { Modulus } \\
(\mathrm{GPa})\end{array}$ & $\begin{array}{c}\text { Poisson's } \\
\text { Ratio } \\
(\mathrm{v})\end{array}$ \\
\hline \multirow{3}{*}{ Andesite } & 5.0 & 38.40 & 33.40 & & & 16.55 & - \\
& 10.0 & 74.14 & 64.14 & 35.20 & 8.00 & 20.48 & - \\
& 20.0 & 92.02 & 72.02 & & & 27.83 & 0.36 \\
\hline
\end{tabular}

Table 6. Dynamic triaxial compression test results

\begin{tabular}{ccccccccc}
\hline Lithology & $\begin{array}{c}\left(\sigma_{3}\right) \\
(\mathrm{MPa})\end{array}$ & $\begin{array}{c}\left(\sigma_{1 \text { stat.max }}\right) \\
(\mathrm{MPa})\end{array}$ & $\begin{array}{c}\left(\sigma_{1 \text { dyn min }}\right) \\
(\mathrm{MPa})\end{array}$ & $\begin{array}{c}\left(\sigma_{1 \text { dyn max }}\right) \\
(\mathrm{MPa})\end{array}$ & $\begin{array}{c}\left(\Delta \sigma_{\text {dyn }}\right) \\
(\mathrm{MPa})\end{array}$ & $\begin{array}{c}\mathrm{f}_{\text {dyn }} \\
(\mathrm{Hz})\end{array}$ & $\begin{array}{c}\mathrm{t}_{\text {dyn }} \\
(\mathrm{sn})\end{array}$ & $\mathrm{n}_{\text {dyn }}$ \\
\hline \multirow{3}{*}{ Andesite } & 5.00 & - & - & - & - & - & - & - \\
& 10.00 & 49.4 & - & - & - & - & - & - \\
& 20.00 & - & 65.0 & 85.4 & 2.55 & 2.00 & 300 & 8 \\
\hline
\end{tabular}

Table 7. Main technical data of some direct shear box devices

\begin{tabular}{l|ccccc}
\hline \multirow{2}{*}{$\begin{array}{c}\text { Direct shear } \\
\text { apparatus }\end{array}$} & $\begin{array}{c}\text { Normal Force } \\
(\mathrm{kN})\end{array}$ & $\begin{array}{c}\text { Shear Force } \\
(\mathrm{kN})\end{array}$ & $\begin{array}{c}\text { Max. shear } \\
\text { displacement } \\
(\mathrm{mm})\end{array}$ & $\begin{array}{c}\text { Shear box } \\
\text { dimensions } \\
(\mathrm{mm})\end{array}$ & $\begin{array}{c}\text { Dynamic } \\
\text { testing }\end{array}$ \\
\cline { 2 - 6 } MTS-816 & 500 & 250 & 100 & $200 \times 200 \times 340$ & No \\
GCTS-RDS-500 & 1500 & 300 & 50 & $100 \times 100 \times 150$ & No \\
TerraTek-DS-4250 & 1000 & 300 & 50 & $150 \times 150 \times 300$ & No \\
HR72.340 & 500 & 750 & - & $350 \times 350 \times 450$ & No \\
LO-50100 & 500 & 500 & 50 & $150 \times 250$ & Yes \\
Huang (1993) & 500 & 500 & 7 & $200 \times 150$ & Yes \\
Barbero (1996) & 9.51 & 17.2 & 20 & $100 \times 100$ & $0 \div 3.5 \mathrm{~Hz}$ \\
Kana (1996) & 333.6 & 222.4 & - & $203 \times 203 \times 101$ & Yes \\
Boulon (1995) & 100 & 100 & - & $100 \times 100$ & No \\
Gehle (2002) & 150 & 150 & 20 & $250 \times 50 \times 150$ & No \\
Hans (2003) & 100 & 100 & - & $100 \times 100$ & Yes \\
Jiang (2004) & 400 & 400 & - & $500 \times 100$ & No \\
Kim (2006) & 150 & 150 & 25 & $140 \times 75$ & No \\
Gomez (2008) & 200 & 200 & 305 & $711 \times 406$ & No \\
Barla (2010) & 100 & 100 & 18 & $\phi 100$ & No \\
Konietzky (2012) & 1000 & 800 & 50 & $400 \times 200 \times 160$ & $0 \div 40 \mathrm{~Hz}$ \\
\hline
\end{tabular}

Beside that, several researchers (Geertsma 2 $\div 02$, Gehle 2002, Seidel \& Haberfield 2002, Jiang et al. 2004, Kim et al. 2006, Gomez et al. 2008, Barla et al. 2010, Konietzky et al. 2012a, Konietzky et al. 2012b, Nguyen 2013) have designed and constructed their own shear box devices to perform direct shear tests. Dynamic shear box testing was reported by several researchers [Huang, et al., 1993; Ahola, et al., 1996;
Bakthar and Barton 1984; Barbero, et al., 1996; Kana, et al., 1996; Fox, et al., 1998; Homand-Etienne, et al., 1999; Lee, et al., 2001; Jafari, et al., 2003; Wang, et al., 2007; Buzzi, et al., 2008]. However, these dynamic shear box devices were developed for tests on significant smaller samples and they are of quite different types. Barbero et al. (1996) have designed and constructed a direct shear testing machine with the purpose 
of testing rock joints under both static and dynamic conditions. Loading capacity of this apparatus in dynamic condition is $10 \mathrm{kN}$, and the frequency range covers $0.01 \div 3.5 \mathrm{~Hz}$. Kana et al. (1996), Ahola et al. (1996) and Fox et al. (1998) developed direct shear testing devices with higher load capacity up to $222 \mathrm{kN}$ and frequencies up to $1.4 \mathrm{~Hz}$. Lee et al. (2001) have designed a servocontrolled direct shear testing machine and attached it to a MTS 815 loading frame. The loading capacity of the testing system is $250 \mathrm{kN}$ and allows cyclic shear motion of up to $\pm 60 \mathrm{~mm}$ displacement. Jafari et al. (2003) used the shear apparatus BCR-3D developed by Boulon (1995) to investigate the effect of cyclic displacements on shear strength of rock joints. Barla et al. (2010) have designed and developed a new direct shear testing apparatus for either soil or soft rock. The maximum loading capacity in the axial and in the shear direction is $100 \mathrm{kN}$ and the maximum shear displacement is $18 \mathrm{~mm}$. Ferrero et al. (2010) developed a new apparatus based on MTS 810 to investigate the behaviour of a rock discontinuity under monotonic and cyclic loads (Nguyen, 2013). A new direct shear device (GS 1000) was developed and installed at the rock mechanics laboratory at the Geotechnical Institute of the TU Bergakademie Freiberg to perform direct shear tests under static, dynamic and hydro-mechanical coupled conditions with extreme high loads (up to $1000 \mathrm{kN}$ ), big shear box dimensions (up to $400 \times 200 \mathrm{~mm}^{2}$ ) and dynamic loads up to $40 \mathrm{~Hz}$ with force amplitudes of up to $\pm 500 \mathrm{kN}$ in both normal and shear directions (Fig. 4). The main technical data of the new direct shear box device GS-1000 are summarized in Table 8.
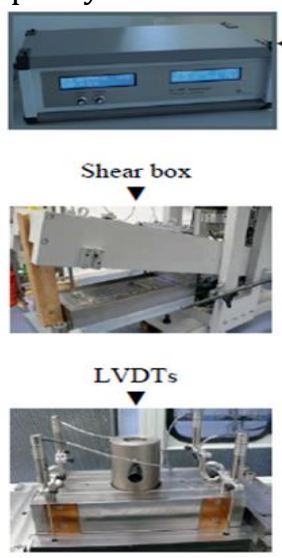

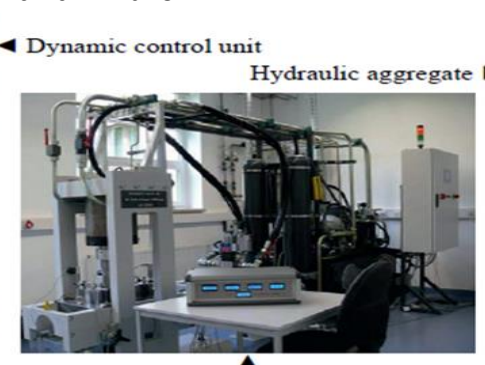

Shear box test device GS-1000

Data logging unit AMs

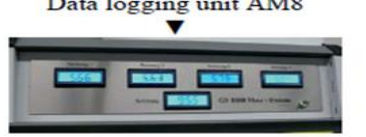

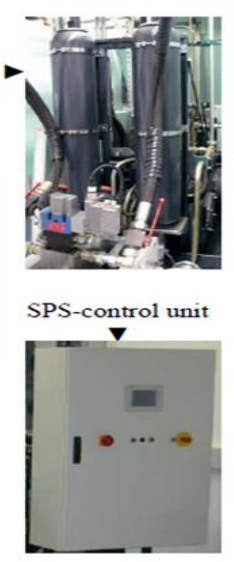

Figure 4. Overview of direct shear test apparatus GS1000

Table 8. Technical data of the GS-1000 apparatus

\begin{tabular}{lcc}
\hline \multicolumn{1}{c}{ Parameter } & Unit & Value \\
\hline Maximum shear displacement & $\mathrm{mm}$ & 50 \\
Shear force & $\mathrm{kN}$ & $-300 \div+800$ \\
Normal force & $\mathrm{kN}$ & $0 \div 1000$ \\
Shear box size (LxWxH) & $\mathrm{mm}$ & $200 \times 400 \times 160$ \\
Frequency & $\mathrm{Hz}$ & $0 \div 40(>40)$ \\
Dynamic loading & $\mathrm{kN}$ & \pm 500 \\
Water pressure (hydro-mechanical coupling) & $\mathrm{MPa}$ & 10 \\
\hline
\end{tabular}




\subsection{Direct Shear Box Testing Methods}

There are two main methods usually used in the laboratory to investigate the shear behaviour of rock joints. They are called constant normal load (CNL) and constant normal stiffness (CNS) tests. CNL means that the normal load is maintained constant during the

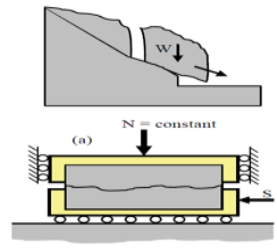

shearing process. Shear testing under CNL boundary condition is suitable for cases such as non-reinforced rock slopes, where the surrounding rock mass freely allows the joint to shear without restricting the dilation, therefore, the normal load on the shear plane is constant during shear process as shown in Figure 5a.
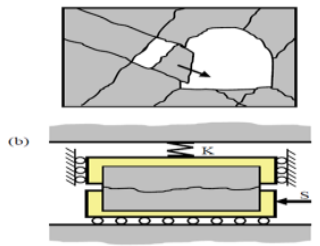

Figure 5. Overview of direct shear test apparatus GS1000

CNS means that the normal stiffness is maintained constant during the shearing process (Figure 5b). Shear testing under CNS boundary condition is usually suitable to investigate the behaviour in deep underground openings or in rock bolt reinforced slopes, where the surrounding rock mass is unable to deform sufficiently and the normal stress acting on the shear plane is not kept constant during the shearing process. In this case, the dilation is controlled by the normal stiffness of the surrounding rock mass. Therefore, the normal stresses on the shear plane increase or decrease with increasing or decreasing dilation, respectively.

\section{Laboratory Shear Box Tests}

\subsection{Shear Strength of Flow Bands} Under Static Loading

Shear strength is the maximum resistance to deformation by continuous shear displacement upon the action of shear stress. $15 \times 15 \times 30 \mathrm{~cm}$ size, total of 6 block sample, locations given in Figure 1 , were obtained to determine shear strength parameters of andesite flow bands under static conditions (Fig. 6; Fig. 7).

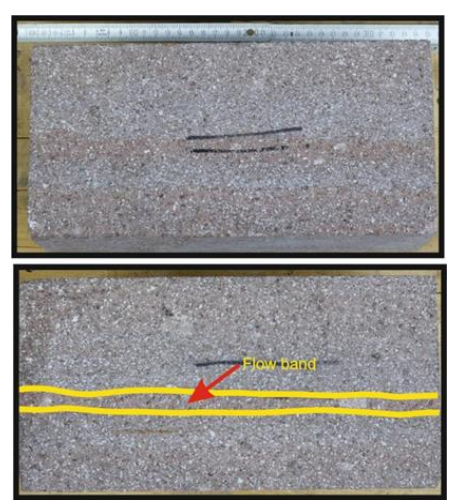

Figure 6. Block sample prepared for shear box test.

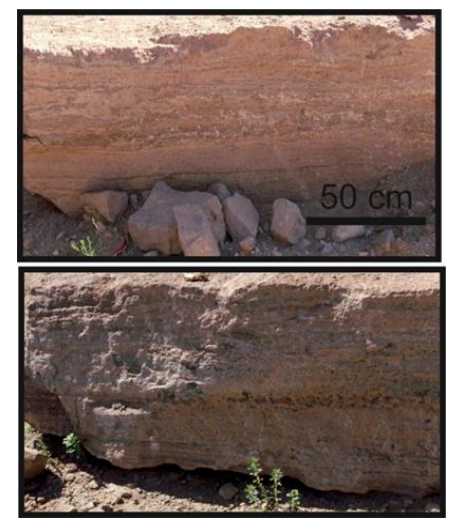

Figure 7. A view of andesite block samples in the field 
The sample preparation and the direct shear tests were conducted according to the recommendation of ISRM (1974) and ASTM (2002). The block samples were placed in the GS 1000 test apparatus and loaded with constant normal stress levels of $3 \mathrm{MPa}, 10 \mathrm{MPa}$, $15 \mathrm{MPa}$ and $20 \mathrm{MPa}$, respectively. During all tests shearing was applied parallel to the flow bands surfaces. Constant shearing displacement velocity was applied with the help of SPS S7 control unit while measurement values for shear and normal deformation were obtained directly at the specimen with AM8 measuring system (Fig.8).

The normal load is measured by a loadcell integrated into the vertical load piston. The shear load is measured by another load-cell connected to the horizontal load piston. Horizontal and vertical displacements are measured by LVDT's (Linear Variable Differential Transformer). Vertical displacement is measured at the four corners at the upper shear frame. Horizontal displacement is measured by a LVDT fixed to the lower shear box part as shown in Figure 8. Accuracy in displacement measurements is in the order of $1 \mu \mathrm{m}$.

During the shear box test shearing movement was started parallel to the flow band surface in the first stage and during the 760 seconds period, $10 \mathrm{~mm}$ shear displacement was applied from left to right under $3 \mathrm{MPa}$ constant normal stress (CNL). Peak shear strength was reached to $5.90 \mathrm{MPa}$ value in the first stage and decreased from this peak point to $2.50 \mathrm{MPa}$ residual shear level. In the second stage, the point moved in such a manner that will be opposite direction (from right to left). In 1340 seconds, there was a shear displacement of $20 \mathrm{~mm}$. during that period. At this step, residual shear strength increased from $2.50 \mathrm{MPa}$ to 3.0 $\mathrm{MPa}$. In the third and final step, the shear displacement moved again from the left to the right by $10 \mathrm{~mm}$ in 650 seconds back to the point at which the test started. In this last step the residual shear strength of the flow band structures was measured as $2.30 \mathrm{MPa}$ (Fig. 9a, Fig. 9b; Fig. 10a, Fig. 10b). During the shear box test, sample showed elastic behavior with small displacements, force which resist shearing strength exceeded after the linear increase in shear strength and shear displacement, stressdisplacement relation lost its linearity and peak shear strength of flow band reached a value of $11.20 \mathrm{MPa}$ under 10 $\mathrm{MPa}$ constant vertical stress. From this point, shear stress decreased to 7.50 $\mathrm{MPa}$ residual shear strength (Fig. 11a; Fig. 11b).

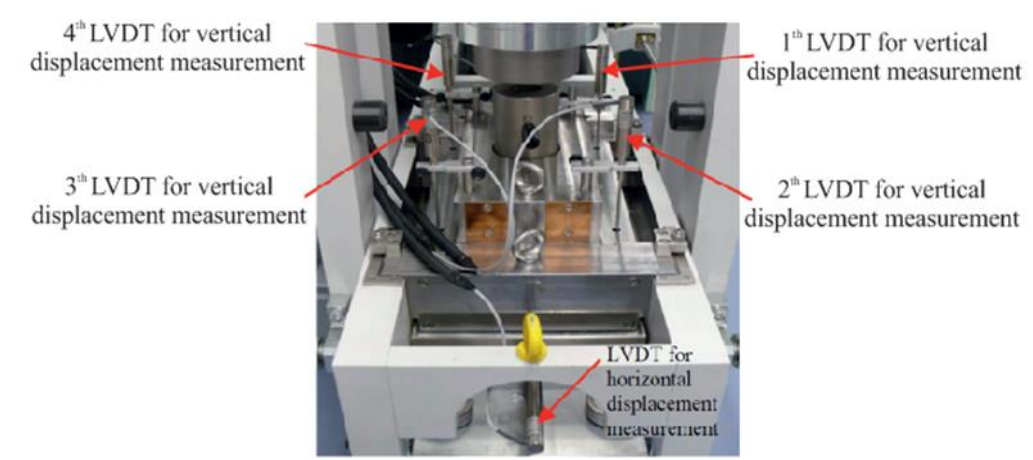

Figure 8. LVDT's view for the normal and shear displacement measurement. 


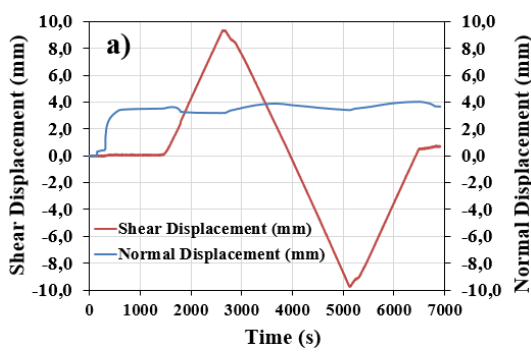

Figure 9a. Relationship between time normal displacement and shear displacement under the $3 \mathrm{MPa}$ normal stress.

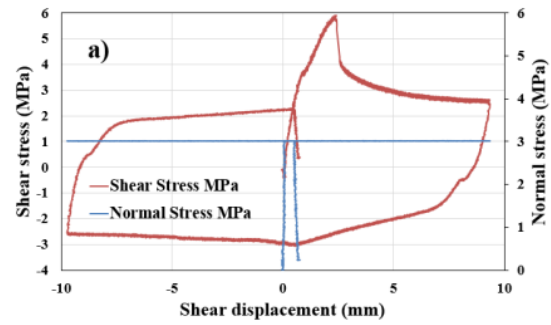

Figure 10 a. Relationship between normal stress, shear displacement and shear stress under the $3 \mathrm{MPa}$ normal stress.

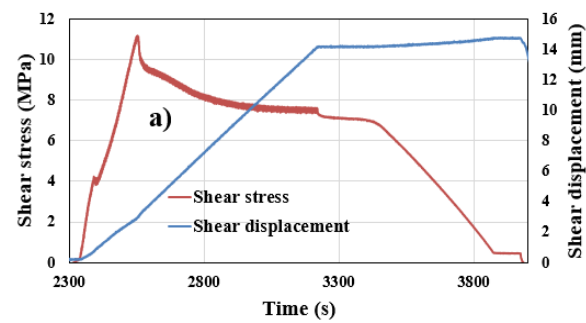

Figure 11 a. Relationship between timeshear stress and shear displacement under the $10 \mathrm{MPa}$ normal stress.

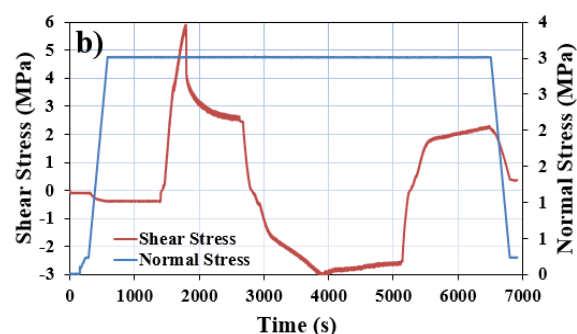

Figure 9b. Relationship between time shear stress and normal stress under the 3 MPa normal stress.

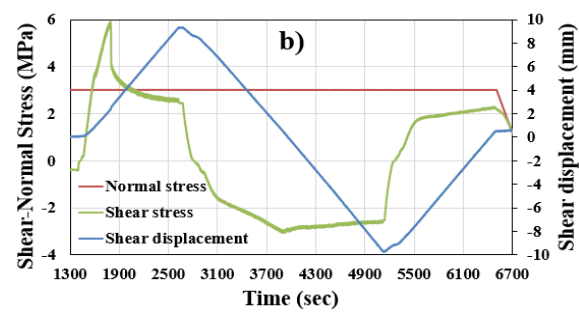

Figure 10 b. Shear test: stresses and shear displacement versus time.

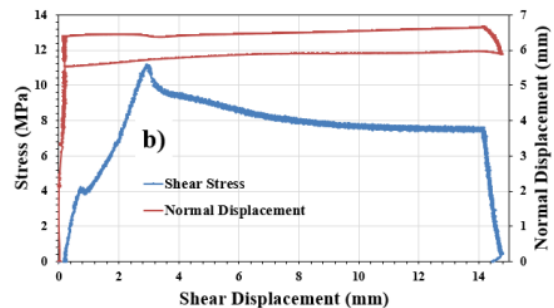

Figure 11 b. Relationship between shear stress, shear displacement and normal displacement under the $10 \mathrm{MPa}$ normal stress.

Shear strength increased with the increase in the normal stresses on flow band structures and vertical displacement decreased and shear displacement became horizontal under the $15 \mathrm{MPa}$ and $20 \mathrm{MPa}$ vertical stress. There is no significant decrease observed in shear strength after the shear failure point under the $15 \mathrm{MPa}$ and $20 \mathrm{MPa}$ vertical stresses (Fig. 12a, Fig. 12b; Fig. 13a, Fig.13b). The behavior of the rock resembles ductile behavior in deformability test $(\sigma-\varepsilon)$ (Fig.15).

Shearing surfaces in between upper shear frame and lower shear frame, formed after shear box tests under the constant normal load conditions, were photographed in detail and were given in Figure 14. 


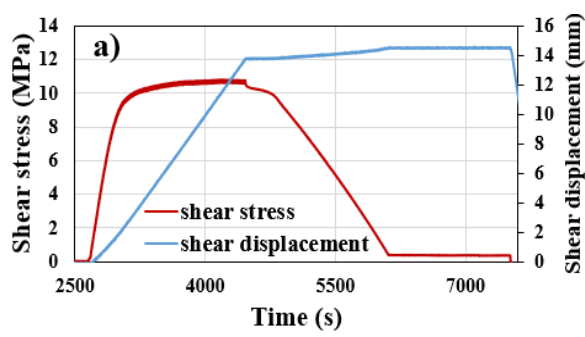

Figure 12a. ) Relationship between time, shear stress and shear displacement under the $15 \mathrm{MPa}$ vertical stress.

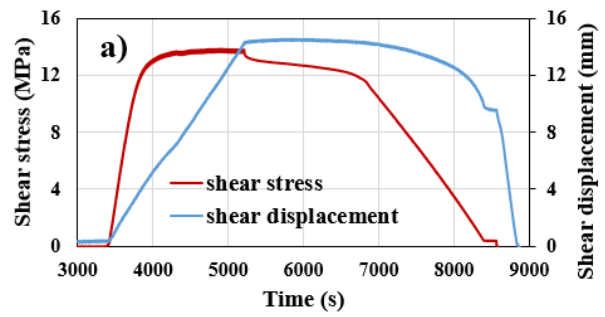

Figure 13 a. Relationship between time, shear stress and shear displacement under the $20 \mathrm{MPa}$ vertical stress.

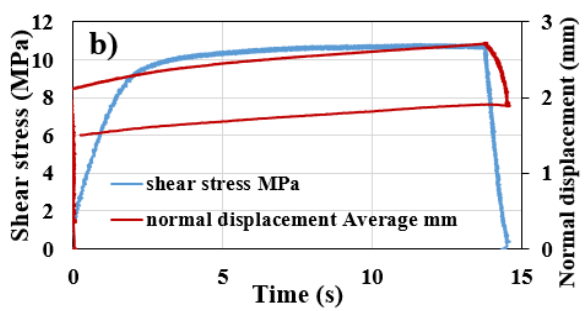

Figure 12 b. Relationship between shear stress, shear displacement and normal stress under the $15 \mathrm{MPa}$ vertical stress.

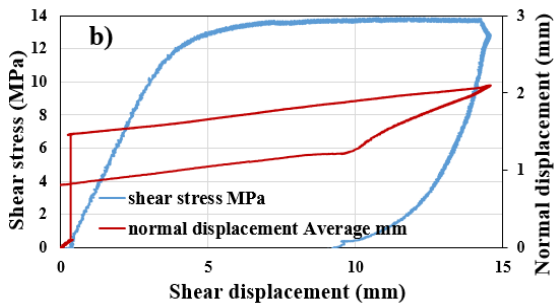

Figure 13 b. Relationship between shear stress, shear displacement and normal stress under the $20 \mathrm{MPa}$ vertical stress.
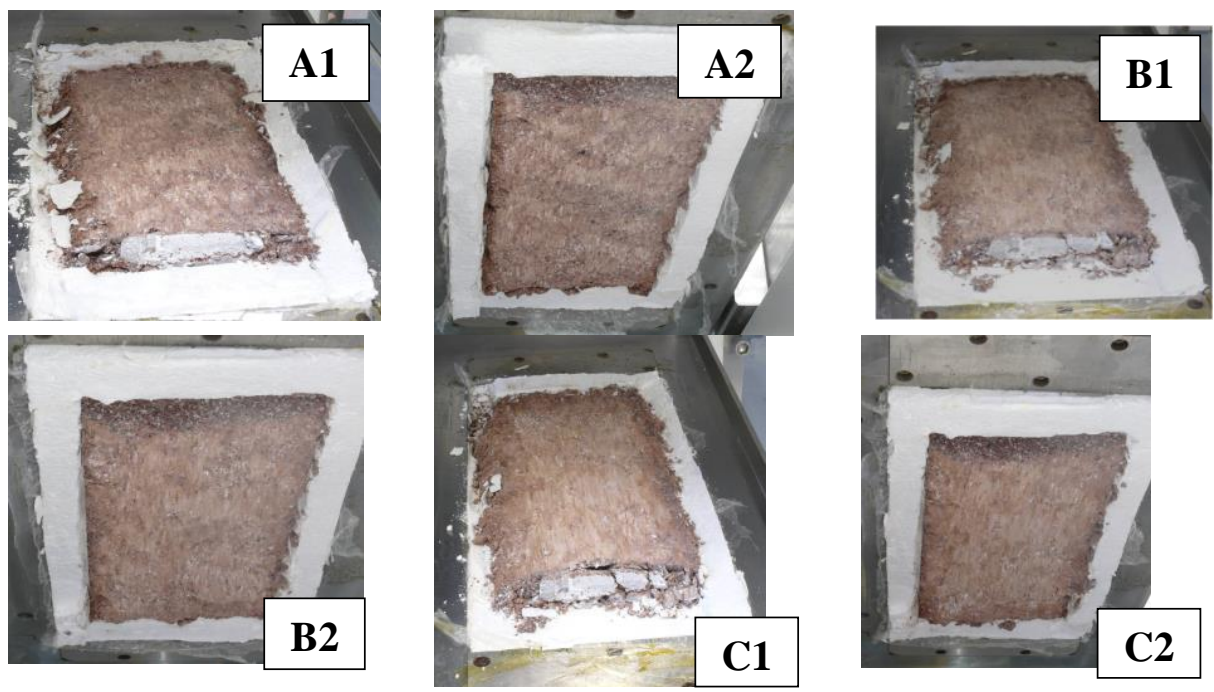

$\sigma_{N}=10 \mathrm{MPa}$ A1: Sheared top surface, A2: Sheared bottom surface, $\sigma_{\mathrm{N}}=15 \mathrm{MPa}$ B1: Sheared top surface, B2: Sheared bottom surface, $\sigma_{\mathrm{N}}=20 \mathrm{MPa}$ C1: Sheared top surface, C2: Sheared bottom surface,

Figure 14. A view from sheared surfaces after the shear box tests. 


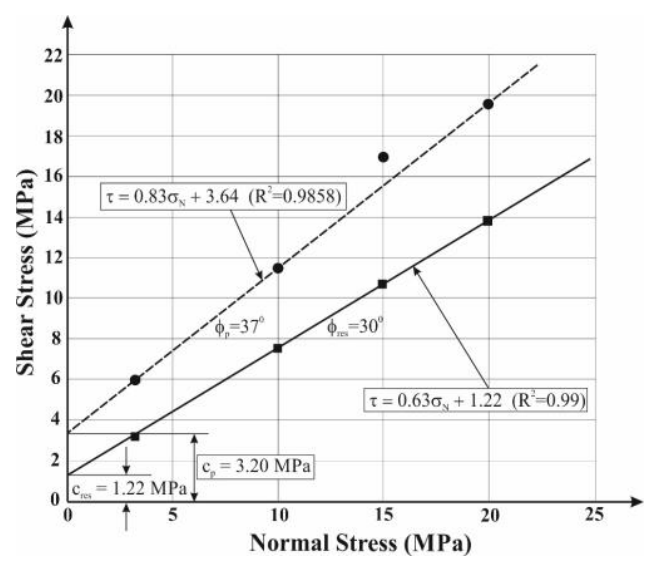

Figure 15. Mohr-Coulomb failure envelope for peak and residual state for flow bands in andesite

\subsection{Shear Strength of Intact Rock}

Figure 15 shows that shear stress of intact rock increases linearly (elastic behaviour) with increasing shear displacement until peak shear strength is reached. After that the shear stress decreases until the residual shear strength (plastic behaviour) is reached. Peak and residual shear strength of intact rock increase as normal load increasies. Peak and residual shear stress of intact rock obtained from laboratory tests under various normal stresses are summarized in Table 9.

Table 9. Peak and residual shear stresses for initial intact rock samples

\begin{tabular}{cccc}
\hline Sample & $\begin{array}{c}\text { Normal stress } \\
\sigma_{\mathrm{n}}(\mathrm{MPa})\end{array}$ & $\begin{array}{c}\text { Peak shear stress } \\
\tau_{\mathrm{P}}(\mathrm{MPa})\end{array}$ & $\begin{array}{c}\text { Residual shear stress } \\
\tau_{\mathrm{R}}(\mathrm{MPa})\end{array}$ \\
\hline 1 & 3.0 & 6.0 & 3.0 \\
2 & 10.0 & 11.7 & 7.5 \\
3 & 15.0 & 17.2 & 10.7 \\
4 & 20.0 & 19.7 & 13.8 \\
\hline
\end{tabular}

Based on the peak and residual shear stresses of flow bands, the MohrCoulomb envelope is constructed for both peak and residual states as shown in Figure 15:

peak state:

$\tau_{\mathrm{P}}=0.75 \sigma_{\mathrm{n}}+3.64\left(\mathrm{R}^{2}: 0.9858\right)$

$\mathrm{CP}=3.64 \mathrm{MPa} ; \quad \phi \mathrm{P}=37^{\circ}$

$\tau_{\mathrm{P}}$ is the peak shear strength, $\tau_{\mathrm{R}}$ is the residual shear strength, $\sigma_{\mathrm{n}}$ is the normal stress, $\phi_{\mathrm{P}}$ is the peak internal friction angle, $\phi_{\mathrm{R}}$ is the residual internal friction angle, $\mathrm{CP}_{\mathrm{P}}$ is the peak cohesion, and $\mathrm{C}_{\mathrm{R}}$ is the residual cohesion.

residual state:

$\tau_{\mathrm{R}}=0.58 \sigma_{\mathrm{n}}+1.22\left(\mathrm{R}^{2}: 0.99\right)$

obtained as;

$\mathrm{C}_{\mathrm{R}}=1.22 \mathrm{MPa} ; \phi_{\mathrm{R}}=30^{\circ}$

\subsection{Shear Strength of Flow Bands} Under Dynamic Loading

The dynamic effect in this work on jointed rock need to be considered. The shear behaviour of joints under dynamic conditions have been studied by many researchers (Bakhtar and Barton, 1984; Barla, et al., 1990; Hobbs, et al., 1990; Hutson and Dowding, 1990; Jing, et al., 1993; Qiu, et al., 1993; Kana, et al., 1996; 
Divoux, et al., 1997; Belem, et al., 2007; Ferrero, et al., 2010; Konietzky, et al., 2012).

Behaviours of the discontinuities under repetitive loads are investigated according to their strain-deformation and strength properties. Straindeformation properties involve dynamic bulk (shear) modulus and damping ratio values and their changes depending on unit deformations, and strength properties involve amplitude of shear stress and number of cycles which cause major deformations. Dynamic shear box tests are conducted to determine the behaviours of the discontinuities under repetitive loads. Field behaviour of the discontinuities can be estimated using empirical equations obtained from laboratory tests.

Table 10. Parameters for dynamic shear testing
The block sample $(15 \times 15 \times 30 \mathrm{~cm})$ was placed in the GS 1000 test apparatus and fixed value of $3 \mathrm{MPa}$ normal stress was applied during the test. Maximum displacement amplitude was applied as (umax) $\pm 10.0 \mathrm{~mm}$ under the $3 \mathrm{MPa}$ normal stress. Shear displacement was allowed as 100 cyle in 110 seconds duration. Parameters for dynamic shear testing are given in Table 10. The shear displacement controlled sinusoidal excitation was applied horizontally to lower half of specimen as follows:

$$
\mathrm{u}_{\mathrm{s}}=\mathrm{u}_{\max } \sin (2 \pi \mathrm{ft})
$$

where;

$\mathrm{u}_{\mathrm{s}}$ is the shear displacement,

$u_{\max }$ is the maximum amplitude of shear displacement,

$\mathrm{f}$ is the frequency, $\mathrm{t}$ is the time.

\begin{tabular}{ccccc}
\hline \multicolumn{5}{c}{ Parameters } \\
\hline LxWxH $\left(\mathrm{cm}^{3}\right)$ & $\sigma_{\mathrm{N}}(\mathrm{MPa})$ & $\mathrm{f}(\mathrm{Hz})$ & $\mathrm{u}_{\max }(\mathrm{mm})$ & Num. of cycle \\
\hline $15 \times 15 \times 30$ & 3.0 & 0.1 & 10.0 & 100 \\
\hline
\end{tabular}

The shear displacement was measured by a horizontal LVDT which is attached to the bottom part of shear box. The normal displacement is also measured by four vertical LVDTs which are positioned at the four corners of the upper part of shear box. The measured shear displacement versus time (100 cycles) for the one tested specimen is illustrated in Figure 16.

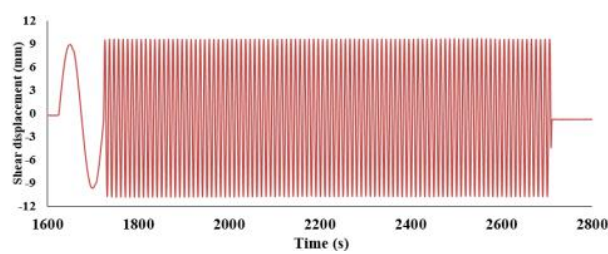

Figure 16. Shear displacement versus time of flow bands in andesitic Rock
The measured shear stress versus time for flow bands is shown in Figure 17. The measured peak shear stresses slightly increase with increasing time and number of cycles, respectively, as shown in Figures 17. This behaviour of the flow bands under dynamic loading is similar to the reported results by Homand-Etienne et al. (1999).

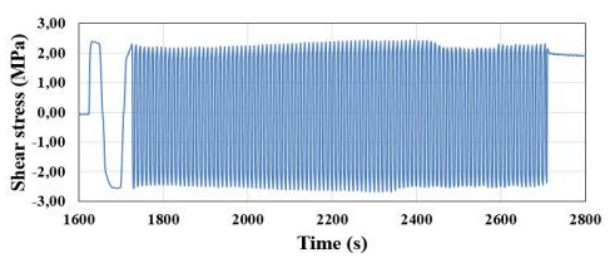

Figure 17. Shear stress versus time of flow bands in andesitic rock 
Experimental results show that the absolute peak shear stress in the negative phases is higher than peak shear stress in the positive phases for flow bands in andesites rock. However, the peak shear stress in positive phases of the flow bands is slightly higher than absolute peak shear stress in the negative phases. The maximum shear stress in the positive and negative phases are given in Table 11.

Table 11. Absolute maximum shear stress

\begin{tabular}{c|c|c}
\hline \multicolumn{2}{c|}{$\begin{array}{c}\text { Absolute maximum shear } \\
\text { stress (MPa) }\end{array}$} & $\begin{array}{c}\text { Cycle } \\
\text { number }\end{array}$ \\
\hline Positive phase & 2.43 & 71 \\
Negative phase & 2.70 & 58 \\
\hline
\end{tabular}

Figure 18 shows the measured shear stress and shear displacement versus time for the dynamic test. This figure reveals a phase shift between shear displacement and shear stress. The shear displacement is phase lagging in comparison with the shear stress. This behaviour of flow bands under dynamic loading was observed during all experiment. These observed results are similar to the results reported by Ahola et al. (1996). The reason for the phase shift between shear stress and shear displacement is associated with chatter of the joint surface and vibrations of the apparatus as reported already by Ahola et al. (1996).

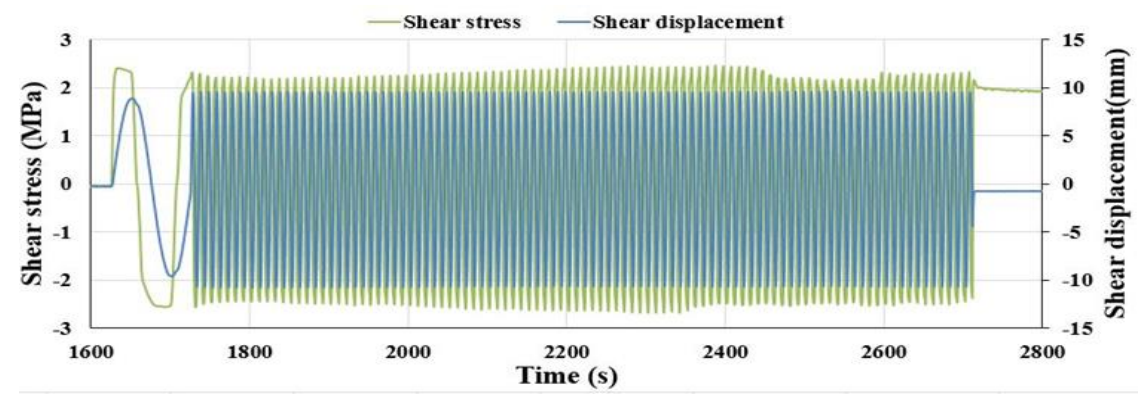

Figure 18. Shear stress and shear displacement versus time of flow bands

The most important issue in many problems of discontinuities under dynamic loads is the relationship between shear strength and unit strain. The relationship between shear strength and unit strain is obtained as a histerisis curve at the end of a full cyle of loading. Stress-strain behavior of the flow bands of andesites under the $100^{\text {th }}$ loading cycle in dynamic shear box test in given in Figure 19. Dynamic bulk modulus (G) can be calculated using the inclination angle of the curve given in Figure 19 as drawing a line connecting the end points of the curve and given as;

$$
\mathrm{G}=\frac{\tau}{\gamma}
$$

$\tau$ is the repetitive shear stress, $\gamma$ is the repetitive shear deformation. Dynamic shear modulus of the flow bands is calculated as $237 \mathrm{MPa}$ using the equation (8).

The energy loss between the shape deformation occur under the repeated loads and the discontinuity surfaces is obtained as damping ratio. The energy loss controls whether the damping ratio is big or small for a material. The damping ratio is estimated using Figure 19 (D) as:

$$
\begin{aligned}
& \mathrm{D}=\frac{1}{4 \pi} x\left(\begin{array}{c}
\frac{\text { Histerisis circle area }}{\text { Area with in }} \begin{array}{c}
\text { the curve } \\
\text { triangular area }
\end{array}
\end{array}\right) \\
& \mathrm{D}=\left(\frac{1}{4 \pi}\right) x\left(\frac{A L}{A T}\right)
\end{aligned}
$$


$\mathrm{AL}$ is the total area in the histerisis, AT is the triangle area in the histerisis. Damping ratio (D) is calculated as 0.634 using the equation (9). Figure 19 shows the shear stress versus shear displacement curves (100 cycles) for flow bands. The andesites specimen is the same and equal to 9. Hence, the maximum shear stresses of andesites specimen were nearly the same, and reached around $2.10 \mathrm{MPa}$ and -2.45 $\mathrm{MPa}$, respectively, under applied normal load of 3.0 MPa. The absolute maximum shear stress of specimen for positive shear displacement phase is similar to that for negative shear displacement phase and reached around $3 \mathrm{MPa}$. The peak dynamic friction angle corresponding to specimen was computed based on the ratio between peak shear and normal stresses. The peak dynamic friction angle averaged after 100 cycles is given in Table 12 .

Peak and residual shear strength of the flow bands were found as $6.00 \mathrm{MPa}$ and $3.00 \mathrm{MPa}$ under the $\sigma_{\mathrm{N}}=3 \mathrm{MPa}$ normal stress and static conditions, respectively.

Table 12. Dynamic friction angles of the flow bands

\begin{tabular}{l|lll}
\multicolumn{1}{c|}{ Flow Bands } & $\sigma_{\mathrm{N}}(\mathrm{MPa})$ & $\tau_{\mathrm{P}}(\mathrm{MPa})$ & $\phi\left(^{\circ}\right)$ \\
\hline Positive phase & 3 & 2.43 & 39 \\
Negative phase & 3 & 2.70 & 42 \\
\hline
\end{tabular}

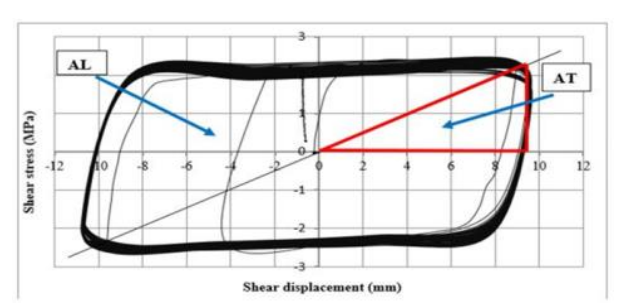

Figure 19. Shear stress versus shear displacement after shearing of 100 cycles of flow bands.
Shear strengths of the flow band structures are found as $2.70 \mathrm{MPa}$ in 58 . cycle and $2.43 \mathrm{MPa}$ in 71 . cycle under the dynamic conditions (Fig. 18). As a result, it was found that peak shear strength of dynamic conditions is $45 \%$ lesser than the one in static conditions.

Peak internal friction angle of the flow bands and residual internal friction angle is calculated as $37^{\circ}$ and $30^{\circ}$ under the static conditions $\left(\sigma_{\mathrm{N}}=3 \mathrm{MPa}\right.$ normal stress), respectively (Fig. 15). Internal friction angle of the flow bands is calculated between the range of $\phi=39^{\circ}$ $-42^{\circ}$ under the dynamic conditions. The variations in normal displacement with time for andesites specimen is shown in Fig. 20 respectively. The normal displacements behave like a harmonic function and continue to decrease with increasing time and number of cycles, respectively. The reason for increasing negative displacements (settlements) during the cyclic shearing is the ongoing degradation of the joint surface. However, the shear movement of one cycle can be subdivided into four different phases: forward advance, forward return, backward advance and backward return phase. The shear and normal displacements for andesite specimens are illustrated in Figure 21 for one cycle.

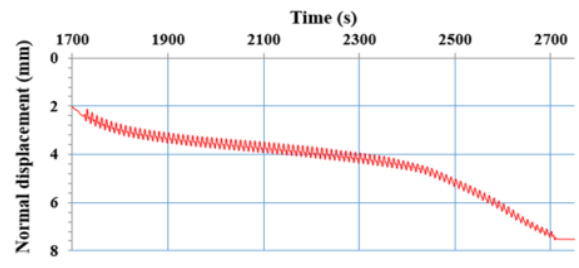

Figure 20. Normal displacement versus time of flow bands. 


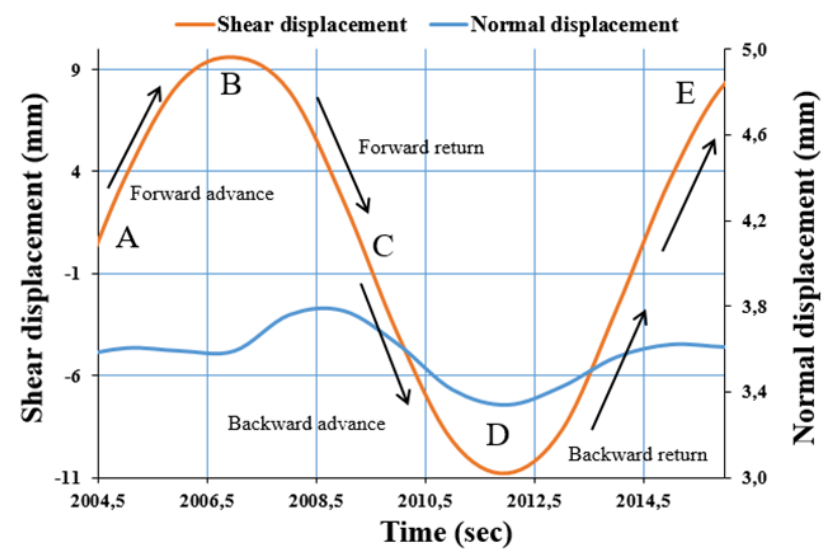

Figure 21. Shear and normal displacements versus time for five cycle of flow bands

The four phases can be characterized as follows:

Phase I (A to B): lower block is moved forward and due to slope direction dilation is negative (compression).

Phase II (B to C): lower block is moving into the opposite direction and due to slope direction dilation is positive (dilation). At point $\mathrm{C}$ the sample has reached again the original position.

Phase III (C to D): lower block is still moving into the opposite direction and dilation is still positive (dilation).

Phase IV (D to E): direction of lower block movement is returned and has the same direction as in phase I, due to slope direction dilation becomes negative (compression).

\section{Results}

Triaxial compression tests were conducted in static conditions and not only cohesion and internal friction angle values were obtained but also the values of Elasticity Modulus and Poisson's ratio $\left(v_{40-60}\right)$ in interval of $0.4 \sigma_{1} \leq \sigma_{u} \leq 0.6 \sigma_{1}$ were calculated in these tests.

$4 \mathrm{kN} / \mathrm{min}$ axial force, $1 \mathrm{MPa} / \mathrm{min}$ cell pressure, $5 \mathrm{kN}$ dynamic axial force applied for 300 seconds during the dynamic triaxial pressure tests, as a result these tests, $\left(\sigma_{1 \text { dyn } \mathrm{min}}\right)$ and $\left(\sigma_{1 \text { dyn }}\right.$ $\max$ ) parameters were obtained.

The shear strength characteristics of flow bands in andesites were investigated considering various initial normal stresses, normal stiffnesses, shear velocities under CNL and dynamic boundary conditions. The direct shear tests were performed up to $20 \mathrm{MPa}$ normal stress equivalent to more than $500 \mathrm{~m}$ in depth.

General results obtained from the static and dynamic shear box tests.

Shear box tests were conducted on 400 x $200 \mathrm{~mm}$ sized rectangle surfaces under the static and dynamic conditions. Time-deformation, timestress, shear displacement-stress; shear displacement -normal displacement, shear displacement -shear stress, normal stress-shear stress relationships were obtained. In addition peak and residual shear strengths, base and residual friction angle values were obtained. 
As shown in Figure 15 and Table 9, equations of the peak and residual shear strength envelopes are as follows;

$\tau_{\mathrm{P}}=0.75 . \sigma_{\mathrm{n}}+3.64\left(\mathrm{R}^{2}=0.98\right)$

$\tau_{\mathrm{R}}=0.58 \sigma_{\mathrm{n}}+1.22\left(\mathrm{R}^{2}=0.99\right)$

It is also seen in Figure 15 and Table 19 that the peak and the residual cohesion values and internal friction angles are $3,64 \mathrm{MPa}, \phi_{\mathrm{P}}=37^{\circ}$ and $1.22 \mathrm{MPa}, \phi_{\mathrm{R}}=$ $30^{\circ}$ respectively.

Using the stress-strain relationship, histerisis curve, obtained from dynamic shear box test, dynamic bulk modulus (G) and damping ratio (D) were calculated. Using the histerisis curve obtained from the graph showing the relation between stress and deformation under the dynamic condition (dynamic shear box test), the values of dynamic Bulk modulus ( $G$ ) and damping ratio (D) were calculated as $237 \mathrm{MPa}$ and 0.634 , respectively.

Reactions against the stress waves of andesitic flow bands and the effects of dynamic loadings on shear behavior of the flow band structures of andesites were investigated under the static and dynamic conditions in shear box tests. Static shear test was carried out under normal stress $\sigma_{N}=3 \mathrm{MPa}$. As a result, it was found to be peak shear stress $\tau_{N}=6$ $\mathrm{MPa}$ and residuel shear stress $\tau_{\mathrm{R}}=3 \mathrm{MPa}$ for the flow bands in andesites. In the dynamic shear test the shear stress of $2.70 \mathrm{MPa}$ at $58^{\text {th }}$ cycle and $2.43 \mathrm{MPa}$ at $71^{\text {st }}$ cycle were found (Fig. 18). Thus, dynamic peak shear stress is $45 \%$ less than the static peak shear stress. Engineering properties of andesitic flow band were defined more realisticly using high pressure loadings and large scale shear box test apparatus. It will be possible to conduct realistic estimates related with earthquake occurences with the help of numerical software analysis using the earthquake sourced dynamic stability and instability data belonging to the andesitic flow bands.

\section{References}

[1] Ahola, M.P., Hsiung, S.M. and Kana, D.D., 1996. Experimental study on dynamic behavior of rock joints. Developments in Geotechnical Engineering. 0. Stephansson, Jing, L., and Tsang, C.F. (Eds). Elsevier Science. 79: 467-494.

[2] Asadi, M.S. and Rasouli, V., 2012. Physical simulation of asperity degradation using laboratorial shear tests of artificial fractures. Rock Engineering and Technology for Sustainable Underground Construction. ISRM International Symposium. Stockholm: 1-14.

[3] ASTM 2002. Performing laboratory direct shear strength tests of rock specimens under constant normal force. D-5607: 1-12.

[4] Bakhtar, K. and Barton, N., 1984. Large scale static and dynamic friction experiments. Proceedings of the 25th U.S. Symposium on Rock Mechanics, The American Institute of Mining, Metallurgical and Petroleum Engineers: 457-466.

[5] Barbero, M., Barla, G. and Zaninetti, A., 1996. Dynamic shear strength of rock joints subjected to impulse loading. Int. J. Rock Mech. Min. Sci. 33 (2), 141-151.

[6] Barla G, Barla M, Camusso $M$, Martinotti, M.E., 2007. Setting up a new direct shear testing apparatus. In: Proceedings of the 11th Congress of the International Society for Rock Mechanics, Lisbon, Portugal, July 2007, Taylor \& Francis, vol 1, pp 415-418.

[7] Barla G., Barla M., and Martinotti M.E., 2010. Development of a new direct shear testing apparatus. 
Rock mechanics and Rock engineering, 43 (1), 117-122.

[8] Barla, G., Barbero, M., Scavia, C., et al., 1990. Direct shear testing of single joints under dynamic loading. Rock joints, Proceedings of International symposium. N. Barton, and Stephansson, O., Eds. Loen, Balkema, Rotterdam: 447-454.

[9] Barton, N., 1976. The shear strength of rock and rock joints. Int. J. Rock Mech. Min. Sci. 13, 255-279.

[10] Belem, T., Mountaka, S. and Homand, F., 2004. Generalized directional peak shear stress criterion for dilatant rock joints. 57th Canadian Geotechnical Conference. Quebec: 1-8.

[11] Belem, T., Souley, M. and Homand, F., 2007. Modeling surface roughness degradation of rock joint wall during monotonic and cyclic shearing. Acta Geotechnica 2 (4): 227-248.

[12] Boulon, M., 1995. A 3-D direct shear device for testing the mechanical behaviour and the hydraulic conductivity of rock joint. Proc. of the MJFR-2 conf., Vienne, Autriche, 407-413, Rossmanith ed., Balkema.

[13] Brady, B.H.G. and Brown, E.T., 2005. Rock Mechanics for Underground Mining, (Third edition), Kluwer Academic Publishers.

[14] Buzzi, O., Boulon, M., Herve, M., et al., 2008. Leaching of rock-concrete interfaces. Rock Mechanics and Rock engineering 41 (3): 445-466.

[15] DGGT (German Geotechnical Society) Empfehlung Nr. 1 des Arbeitskreises Versuchstechnik Fels (revised recommendation) 2004b. Einaxiale Druckversuche an zylindrischen Gesteinsprüfkörpern (Uniaxial compression tests on rock specimens). Bautechnik 81, $825-834$.
[16] Divoux, P., Boulon, M. and Bourdarot, E., 1997. A mechanical constitutive model for rock and concrete joints under cyclic loading. Proceedings of Damage and Failure of Interfaces. H. P. Rossmanith, (Ed). Vienna, Austria: 443-450.

[17] Ferrero, A.M., Migliazza, M. and Tebaldi, G., 2010. Development of a new experimental apparatus for the study of the mechanical behaviour of a rock discontinuity under monotonic and cyclic loads. Rock Mechanics and Rock Engineering 43 (6), 685-695.

[18] Fox, D.J., Kana, D. D. and Hsiung, S. M., 1998. Influence of interface roughness on dynamic shear behavior in jointed Rock. Int. J. Rock Mech. Min. Sci. 35 (7): 923940.

[19] Geertsema A.J., 2002. The shear strength of planar joints in mudstone. Int. J. Rock Mech. Min. Sci., 39, 1045-1049.

[20] Gehle C., 2002. Bruch- und scherverhalten von gesteinstrennflächen mit dazwischenliegenden materialbrücken. In Published by Faculty of Civil Engineering, RuhrUniversity Bochum.

[21] Gentier, S., Riss, J., Archambault, G., et al., 2000. Influence of fracture geometry on shear behavior. Int. J. Rock Mech. Min. Sci. 37, 161-174.

[22] Gomez, J.E., Filz, M.G., Ebeling, R.M., et al., 2008. Sand-to-Concrete interface response to Complex load paths in a large displacement shear box. Geotechnical Testing Journal 31 (4), 1-12.

[23] Grasselli, G. and Egger, P., 2003. Constitutive law for the shear strength of rock joints based on three-dimensional surface parameters. Int. J. Rock Mech. Min. Sci 40 (1), 25-40. 
[24] Haberfield, C.M. and Seidel, J.P., 1999. Some recent advances in the modelling of soft rock joints in direct shear. Geotechnical and Geological Engineering 17, 177195.

[25] Haque, A., 1999. Shear behaviour of soft rock joints under constant normal stiffness. Published by Department of Civil, Mining and Environmental Engineering, 1-293.

[26] Hobbs, B.E., Ord, A. and Marone, C., 1990. Dynamic behaviour of rock joints. Rock joints, Proceedings of International symposium. N. Barton, and Stephansson, O., (Eds). Loen, Balkema, Rotterdam, 435-445.

[27] Hoek, E., 2007. Practical Rock Engineering. RocScience: 1-237.

[28] Homand-Etienne, F., Lefevre, F., Belem, T., et al., 1999. Rock joints behavior under cyclic direct shear tests. Proc. 37th U.S. Rock Mechanics Symp. Colorado U.S.A, Balkema: 399-406.

[29] Huang, X., Haimson, B.C., Plesha, M.E., et al., 1993. An investigation of the mechanics of rock joints part 1. laboratory investagation. Int. J. Rock Mech. Min. Sci. 30 (3), 257-269.

[30] Hutson, R.W. and Dowding, C.H., 1990. Joint asperity degradation during cyclic shear. Int. J. Rock Mech. Min. Sci. 27 (2), 109-119.

[31] ISRM 1974. Suggested methods for determining shear strength. Committee on standardisation of Laboratory and Field tests, pp 123.

[32] ISRM 2007. The complete ISRM suggested methods for rock characterization, testing and monitoring: 1974 - 2006. Compilation arranged by the ISRM Turkish National Group, Ankara, 2007.

[33] ISRM, 1981. Rock characterisation testing and monitoring ISRM suggested methods. Brown, E.T., (Editor), Pergamon Press.

[34] ISRM, 1983. Suggested methods for determining the strength of rock materials in triaxial compression. Revised version. Int. J. Rock Mech. Min. Sci. \& Geomech. Abstr. 20, 285 $-290$.

[35] Jafari, M.K., Hosseini, K.A., Pellet, F., et al., 2003. Evaluation of shear strength of rock joints subjected to cyclic loading. Soil Dynamic and Earthquake Engineering 23: 619630.

[36] Jiang, Y., Li, B. and Tanabashi, Y., 2006. Estimating the relation between surface roughness and mechanical properties of rock joints. Int. J. Rock Mech. Min. Sci. 43, 837-846.

[37] Jiang, Y., Xiao, J., Tanabashi, Y., et al., 2004. Development of an automated servo-controlled direct shear apparatus applying a constant normal stiffness condition. Int. J. Rock Mech. Min. Sci. 41, 275-286.

[38] Jing, L., Stephansson, O. and Nordlund, E., 1993. Study of rock joints under cyclic loading conditions. Rock Mechanics and Rock Engineering 26 (3), 215-232.

[39] Kana, D.D., Fox, D.J. and Hsiung, S.M., 1996. Interlock/Friction model for dynamic shear response in natural jointed Rock. Int. J. Rock Mech. Min. Sci. 33 (4), 371-386.

[40] Kim D.Y., Chun, B.S. and Yang, J.S., 2006. Development of a direct shear apparatus with rock joints and its verification tests. Geotechnical testing, 29 (5).

[41] Kim, D.Y. and Lee, Y.N., 2007. New peak shear strength criteria for anisotropic rock joints using quantified joint roughness parameters. 11th Congress of the International Society for Rock mechanics. Lisbon, 355-358. 
[42] Koca, M.Y. \& Kincal, C., 2004. Abandoned stone quarries in and around the Izmir city centre and their geoenvironmental impacts. Engineering Geology 75, 49-67.

[43] Koca, M.Y., 1995. Slope stability assessment of the abandoned Andesite quarries in and around the Izmir city centre. PhD Dissertation. Dokuz Eylul University, Graduate School of Natural and Applied Science, Izmir, Turkey.

[44] Koca, M.Y., Ozden, G., Yavuz, A.B., Kincal, C., Onargan, T. and Kucuk, K., 2006. Changes In Engineering Properties of Fire Exposed Marble Columns. Int. Jour. of Rock Mech.\& Min. Sci., Elsevier, Vol. 43, Issue 4.

[45] Kodikara, J.K. and Johnston, I.W., 1994. Shear behaviour of irregular triangular rock-concrete joints. Int. J. Rock Mech. Min. Sci. 31 (4), 313322.

[46] Konietzky, H., Frühwirt, T., Luge, H., 2012b. A new large dynamic rockmechanical direct shear box device. In: Rock Mechanics Rock Engineering, 45 (3): 427-432.

[47] Konietzky, H., Frühwirt, T., Nguyen, V.M., 2012a. GS 1000: A new large rockmechanical shear box device for dynamic and HM-coupled testing under extreme strong froces. In: Proc. EUROCK 2012, 1-9.

[48] Lee, H.S., Park, Y.J., Cho, T.F., et al., 2001. Influence of asperity degradation on the mechanical behavior of rough rock joints under cyclic shear loading. Int. J. Rock Mech. Min. Sci. 38: 967-980.

[49] Luge, H., 2011. Entwicklung, Aufbau und Versuchssteuerung für ein neuartiges dynamisches hydromechanisches Felsschergerät für extrem hohe Kräfte. Published by Geotechnical Institute, TU Bergakademie Freiberg.
[50] Nguyen, V.M., 2013. Static and dynamic behaviour of joints in schistose rock: Lab testing and numerical simulation. Publ. Geotechnical Institute 2013-3 (ed. H. Konietzky), TU Bergakademie Freiberg, Germany.

[51] Ohnishi, Y. and Dharmaratne, P.G.R., 1990. Shear behaviour of physical models of rock joints under constant normal stiffness conditions. Proceedings of the international conference on rock joints, Balkema, Rotterdam, 267273.

[52] Qiu, X., Plesha, M.E., Huang, X., et al., 1993. An investigation of the mechancis of rock joints - Part II. Analytical investigation. Int. J. Rock Mech. Min. Sci. 30 (3), 271-287.

[53] Seidel, J.P and Haberfield, C.M., 2002. Laboratory testing of concrete-rock joints in constant normal stiffness direct shear. Geotechnical Testing, 25 (4).

[54] Wang, W.H., Li, X.B., Zhang, Y.P., et al., 2007. Closure behavior of rock joint under dynamic loading. Jour. Cent. South Univ. Technol., 408-412. 